\title{
Lone Mothers and Their Children
}

\author{
JANE ROBERTS
}

'Single mothers' have been caught in the crossfire of political debate in recent times. On the one hand, they are portrayed as the epitome of a permissive age, a sign of moral degeneracy, whereas on the other hand they are defended by the argument that it is the poverty to which they are driven that solely accounts for their adversities. But who are we talking about? What are the outcomes for the children of lone mothers? What might account for some of the difficulties faced by children who live at least part of their lives in a lone mother household?

\section{Definition}

The most commonly used definition of a one-parent family is that adopted by the 1974 Finer Report (Department of Social Security, 1974) on one-parent families, "a mother or father living without a spouse (and not cohabiting) with his or her never-married dependent child or children". Much of the data available comes from the General Household Survey (GHS), which now uses the term, lone parents, and includes single (never married), widowed, divorced and separated mothers. Prior to 1986, individuals in the GHS were not specifically asked whether or not they were cohabiting and therefore the figures for lone mothers included both those who were in a stable cohabiting relationship and those who were also legally single but without a partner. Even now, the GHS does not take account of a history of cohabitation so that mothers who have given birth to a child while in a cohabiting relationship which has subsequently dissolved, will be classed as single, with no differentiation made from those who never lived with the father of their child.

\section{Demographic picture}

The proportion of all births that occur outside of marriage has hugely increased from $12 \%$ in 1980 to $30 \%$ in 1991 , but so have the numbers of jointly registered births, from $58 \%$ of all births to $75 \%$ within the same time span (Kiernan \& Estaugh, 1993). Thus, the suggestion that since 1971, the number of lone parent families has more than doubled to around 1.3 million in 1991 (Haskey, 1993) needs to be qualified. The General Household Survey (1992) reveals less ambiguously that lone parent families now make up $21 \%$ of all families in Britain and that $90 \%$ are women-lead. Widowhood accounts for a declining proportion (6\%) of all lone parent families while marriage breakdown contributes to just over a half (52\%) (Burghes, 1993). There was a trebling in the number of divorced lone mothers between 1971 and 1989. The fastest growing group of lone parents are however single, never married, mothers who accounted for $37 \%$ of all lone parent families in 1992, a rise in proportion of all families from $1 \%$ in 1971 to $7 \%$ in 1992 . Britain has now the highest proportion of lone parent families in the European Union, having overtaken even Denmark. As far as any individual parent and child is concerned, however, the picture is highly fluid: lone parent families are continually being formed, dissolved, reformed or differently formed, through marital breakdown, cohabitation and remarriage. Flows out of lone parenthood are higher for single lone mothers: they stay living without a partner for a median of three years compared with separated and divorced mothers who remain lone for a median of five years. There is some suggestion now that there are two distinct groups of women who are turning away from marriage: professional, independent women who have too much to lose from a legal partnership and women from economically depressed areas who have too little to gain from marriage to men with few employment prospects.

Many earlier research studies made no distinction between different types of single mothers and their different characteristics. This has confounded analysis of the implications of lone motherhood for children and the mechanisms involved. Single, never married, mothers tend to be younger and to have smaller and younger families (an average of 1.4 children and $60 \%$ under 5 years) (Burghes, 1993). There is a higher rate of single motherhood within the population of AfroCaribbean origin. Of all lone parents, single mothers are most likely to be living with their parents, around 1 in 5, and to receive Income Support (76\%) (Kiernan \& Estaugh, 1993). Twenty-seven per cent are employed but the younger the single mothers are, the less likely they are to be in work. Planned parenthood increases with age: in the USA, the greatest increase in births to single women between 1970 and 1984 occurred among women over 30 . Among this group of 'single mothers by choice', there appear to be consistent 
differences between those who pre-planned the pregnancy and those who decided to keep the child once the pregnancy was known (Pakizegi, 1990).

Births jointly registered by parents who appear not to be living together represent $20 \%$ of all extramarital births and will include an unknown proportion of 'living apart together' relationships about which there is little information (Kiernan \& Estaugh, 1993). Divorced women are likely to be in their mid-thirties with three-quarters of their children between 5 and 15 years old and, in 1986, 59\% were receiving Income Support. Just over half of divorced mothers are in work. Although slightly younger, the characteristics of separated women, not surprisingly, are similar. It looks as though they are a different group, however, with one estimation that three-quarters of separated women were not intending to get divorced (Bradshaw \& Millar, 1991). Not unexpectedly, widowed lone mothers are the oldest of the group (over a quarter over 50), the least likely to move home and the least impoverished.

\section{Implications for children}

What are the implications for the children in these different types of families? How far can we attempt to answer this question in the light of the bewildering mass of available data? Definitions of lone/one/ single-parent families may not be consistent between studies, and different studies explore different constellations of children from single/divorced and separated/widowed mothers. Furthermore, by taking a snap-shot view and not taking into account the dynamic nature of family types, studies may group together what are in fact very heterogeneous families.

One of the earliest studies was of children born 'illegitimate' (a term made redundant by the Family Law Reform Act 1987), from the 1958 cohort of the National Child Development Study; this showed that the behaviour, adjustment and attainment at school of these children at seven years old was poorer than that of the children born legitimately. There were major differences, however, in environment between the two samples: considerable downward social mobility had occurred among the mothers who kept their 'illegitimate ' babies (Crellin et al, 1971). Ferri's study published in 1976 was set up to give evidence to the Finer Committee and investigated all children "being cared for by a natural mother or father alone, without help from a parent substitute of the opposite sex living in the same household". Such children were found to be less well adjusted at home and at school. The girls whose fathers were absent attended school less regularly and the fatherless boys were more likely to be enuretic at the age of eleven. Ferri stressed, however, that the differences in behaviour and adjustment were small in magnitude and that her findings had suggested that the absence of the parent itself had not had the "overwhelmingly detrimental effect so often attributed to it".

\section{Divorced family studies}

With the dramatic rise in divorce over the last 20 years, most recent studies have focused on children of divorced families and come predominantly from the USA. Many studies have looked at the impact on children of living in lone-parent families in terms of their emotional development, behaviour, likelihood of psychiatric disorder, attainment and educational performance, gender identity and later attitudes towards marriage, values and timing of lifecycle transitions (Emery, 1988; Amato \& Keith, 1991; Barber \& Eccles, 1992). On the whole, these and other studies indicate that children of lone parents have a small but increased risk of poorer outcomes across a wide range of measures than children living with both parents. For example, Wadsworth et al (1985) demonstrated that five-year-olds from oneparent families were perceived to behave in a more antisocial manner, to be marginally more 'neurotic' and scored worst on tests of vocabulary and visuomotor coordination, compared with children from two-parent and step-families.

\section{Important variables}

Maternal age, however, rather than family type was a more significant influence on outcomes, children faring worse with young mothers. Blum et al (1988) demonstrated that children of lone parents were at higher risk of conduct disorder and poor school performance but that, after controlling for income, the relationship became non-significant. Family dysfunction was the variable that made the strongest independent contribution to child psychiatric disorder. Children of widows fare better than those of other lone single mothers, often differing little from their peers in intact families (Kiernan, 1992; Burghes, 1994). Children in divorced families, in contrast, are more likely to show multiple behaviour problems and have fewer psychological resources on which to draw in times of stress (Hetherington, 1991). Their difficulties, however, have been shown often to have been present several years before a parental divorce (Block et al, 1986; Elliott \& Richards, 1991). The response of children to disposition, whether by separation, divorce, or remarriage is thought by many but not all to depend on their age and sex (Block et al, 1986; Elliott \& Richards, 1991; Hetherington, 1991; Kurdek, 1991). 
Much less attention has been paid to the children of single mothers though, with the rise in their number, it is likely that this will be rectified in future. One of the few studies in this area described 10 out of 17 six-year-old children of 'elective single mothers' as having a 'ghost father', about whom they knew very little but accounted for his absence by feeling rejected and blaming themselves. Mothers felt uncomfortable discussing the father with their children who, in turn, asked few questions (Rose, 1992). These were all children conceived naturally: what of children conceived by artificial insemination? AID has been discussed from the perspective of the mother but the resulting children have been given scant consideration.

\section{Parenting skills}

While children of lone mothers generally do worse than their peers in two-parent families, some children fare very well. What makes for successful lone parenting? How far have we got in teasing out the mechanisms involved? There is a substantial body of evidence that authoritative parenting is associated with better child adjustment whatever the family type, but parenting skills are only a part, albeit crucial, of the story. A number of factors have been put forward to account for the adversities faced by the children of lone mothers: absence of the father, the impoverished economic circumstances of lone mothers, the stigma and lower expectations of their children, the experience of conflict in divorced and separated families, the psychological well-being of the lone mother and the characteristics of family dynamics in a lone mother household. None of these suggestions is of course mutually exclusive. A metaanalysis of 92 studies by Amato \& Keith (1991) compared the evidence for parental loss, economic deprivation and family conflict as mediating factors in the poorer outcome of children of divorced lone parent families. Although there was some support for all three, none accounted fully for the pattern of findings. Parental absence was the least well supported, whilst economic disadvantage was thought to play a significant role. Even after income was controlled for, however, differences remained between the children in divorced compared with intact families. There was considerable support for the family conflict perspective; children in high-conflict intact families scored significantly lower in psychological adjustment and self-esteem, compared both with children from low-conflict intact families and divorced families. Those studies which demonstrate difficulties in children some years prior to parental divorce are consistent with the conflict perspective
(Block et al, 1986; Elliott \& Richards, 1991). There was further support from a study in which mothers in low marital conflict rated their children's adjustment higher than mothers in high marital conflict and separated/divorced mothers, an effect that persisted even when mothers' depression and socioeconomic variables were controlled for (Kurdek, 1991). Children of never married mothers may well have relatively little experience of conflict in the home and hence other factors will be more important, though we know relatively little about this subgroup.

\section{Parental health}

The health of lone parents is significantly lower than that of their married counterparts with reports of highest ill-health from separated lone mothers, followed by divorced and then never married mothers. Material deprivation, the effects of disruption and social isolation are all thought to be factors (Popay \& Jones, 1990). Lone mothers with dependent children have reported the highest rate of psychiatric symptoms, particularly anxiety and depression.

\section{Maternal work status}

Difficulty in coping in such circumstances, however, arose only with the mother working full-time rather than part-time. There is a complicated relationship between maternal work status and children's adjustment; it may be that it is the congruence between maternal employment preference and her work that is the important issue. The woeful lack of affordable, high quality child care in this country is obviously a pertinent issue. It is the quality of substitute care that is the most significant factor in determining its consequences for the emotional health of a child but it does not come cheap; lone parents and their children are therefore particularly disadvantaged. Older children may take on a caring role for younger siblings, or indeed for their mothers, perhaps borne out by the decreased school attendance of some children of lone mothers. Hetherington (1991) has commented on the intimacy that may border on enmeshment, together with anger and conflict that often is present in divorced, non-remarried families.

\section{Future directions}

There is some evidence from the USA that the consequences of divorce for children have lessened to some extent since the 1950s and 1960s (Amato \& Keith, 1991), consistent with the increased social acceptance of divorce since that time. Much, however, 
remains to be disentangled about the effects on children of lone motherhood. Many lone mothers bring their children up very successfully and this should be acknowledged ungrudgingly. A secure attachment to a single parent bestows enormous benefits to children and, crucially, to future generations. We are particularly ignorant about the small, but heterogeneous group of children of never married mothers. What are the effects on those children, girls and boys, who have had little, if any contact with their father? Or seen a number of men pass through the household? What sense of manhood will boys have in such circumstances? Future research should be directed towards making a meaningful comparison of the mental health of children of different groups of lone mothers. Deriving discrete groups in such fluid times would, however, be no easy task: differentiating for example between divorced families in which there had been pre-divorce conflict or not and, within the never married group, between those with none, one or more successive male partners. The political contention surrounding the field is not auspicious for a cool examination of the evidence. It is clear, however, that although mothers may choose not to have a partner, children can never choose not to have a father, he will exist in fantasy, even if not in person.

\section{References}

Amato, P. R. \& Keith, B. (1991) Parental divorce and the wellbeing of children: a meta-analysis. Psychological Bulletin, 110, 26-46.

BARBer, B. L. \& ECCLES, J. S. (1992) Long-term influence of divorce and single parenting on adolescent family- and workrelated values, behaviours and aspirations. Psychological Bulletin, 111, 108-126.

BLock, J. H., BLoCk, J. \& GJerde, P. F. (1986) The personality of children prior to divorce: A prospective study. Child Development, 57, 827-840.

Blum, H. M., Boyle, M. H. \& Offord, D. R. (1988) Single -parent families: child psychiatric disorder and school performance.
Journal of the Academy of Child and Adolescent Psychiatry, 27, 214-219.

Bradshaw, J. \& Millar, J. (1991) Lone Parent Families in the UK. Department of Social Security Research Report, 6, HMSO. Burohes, L. (1993) Lone Parents: Policy Options for the 1990's. Family Policy Studies Centre and Joseph Rowntree Foundation. - (1994) Lone Parenthood and Family Disruption. The Outcomes for Children. London: Family Policy Studies Centre and Joseph Rowntree Foundation.

Creluin, E., Krllmer Prinole, M. L. \& West, P. (1971) Born Illegitimate. Social and Educational Implications. National Foundation for Educational Research in England and Wales. Department of Health And Social Securtty (1974) Report of the Committee on One Parent Families. London: HMSO.

ELuOTT, B. J. \& RICHARDS, M. P. M. (1991) Children and divorce: educational performance and behaviour before and after parental separation. International Journal of Law and the Family, 5, 258-276.

EMERY, R. E. (1988) Marriage, divorce and children's adjustment. Newbury Park, CA: Sage.

General Household Survey (1992) OPCS, hMSO.

KizRnan, K. E. (1992) The impact of family disruption in childhood on transitions made in young adult life. Population Studies, 46, 213-234.

\& EstauGH, V. (1993) Cohabitation. Extra-Martial Childbearing and Social Policy. Occasional Paper 17, Family Policy Studies Centre.

KURDEK, L. A. (1991) Differences in ratings of children's adjustment by married mothers experiencing low marital conflict, married mothers experiencing high marital conflict, and divorced single mothers: a nationwide study. Journal of Applied Developmental Psychology, 12, 289-305.

Hasxey, J. (1993) Lone parents and married parents with dependent children in Great Britain: a comparison of their occupation and social class profiles. Population Trends, 72, 34-45.

Hetherinoton, E. M. (1991) Presidential address: families, lies, and videotapes. Journal of Research on Adolescence, 1, 323-348.

PakizBoI, B. (1990) Emerging family forms: single mothers by choice - demographic and psychosocial variables. MaternalChild Nursing Journal, 19, 1-19.

Popay, J. \& Jones, G. (1990) Patterns of health and illness amongst lone parents. Journal of Social Policy, 19, 499-534.

Rose, M. K. (1992) Elective single mothers and their children: the missing fathers. Child and Adolescent Social Work, 9, 21-33.

WADSWORTH, J., BurNell, I., TAYLOR, B., et al (1985) The influence of family type on children's behaviour and development at five years. Journal of Child Psychology and Psychiatry, 26, 245-254.

Dr Jane Roberts, Camden and Islington Community Health Services NHS Trust, Hornsey Rise Child and Family Therapy Service and The Whittington Hospital, London N19

(First received 10 October 1994, final revision 1 February 1995, accepted 20 March 1995) 